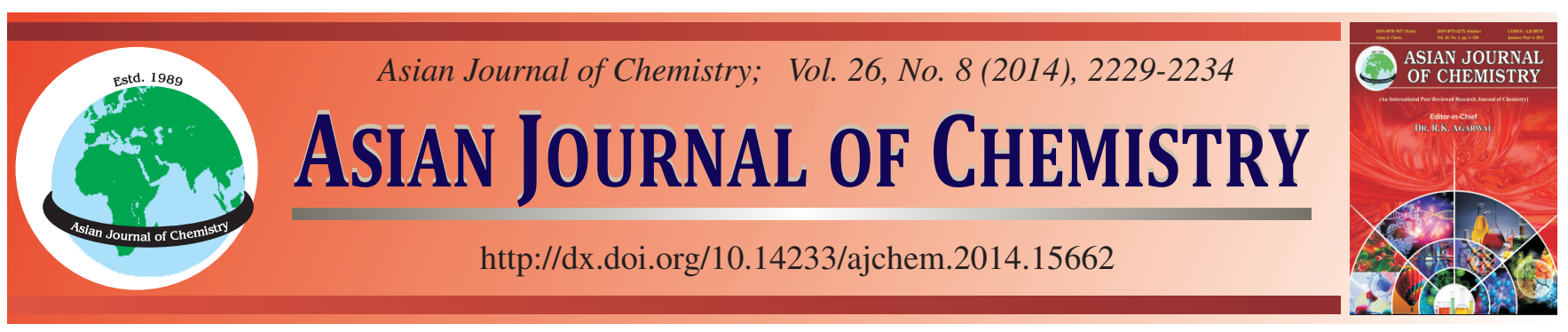

\title{
Novel Donor $\pi$-Acceptor Conjugates-Functionalized Zinc Phthalocyanines Application in Dye-Sensitized Solar Cells
}

\author{
Xuejun Zhang*, Meiling Wang, Huipeng He and Lijun Mao
}

Department of Chemistry, School of Science, North University of China, Taiyuan 030051, Shanxi Province, P.R. China

*Corresponding author: Tel/Fax: +86 351 3922152; E-mail: zhangxuejun@nuc.edu.cn

Keywords: Dye-sensitized solar cells, Phthalocyanine, Iminodiacetic acid, Carboxy group, Unsymmetrical, Redox electrolyte.

\section{INTRODUCTION}

Harvesting energy directly from sunlight using photovoltaic cells is recognized worldwide as an important solution to the growing energy crisis and environmental pollution. In the past decade, low band-gap organic molecules ${ }^{1-6}$ and conjugated polymers ${ }^{7-11}$ with internal electron donor- $\pi$-acceptor interaction have been developed and received continued interest towards highly efficient dye-sensitized solar cells (DSSCs). In dyesensitized solar cells the light absorption function is fulfilled by the dye and the electron and hole transporting are fulfilled by the nanocrystalline metal oxide and electrolyte. Therefore the absorption properties of the dye dictate the light-harvesting capacity of the cell.

Phthalocyanines, as planar, two-dimensional aromatics, have emerged as a promising molecular component. The application of phthalocyanines into photovoltaic devices is usually performed in blends together with semiconductor polymers and/or acceptor molecules such as fullerenes via vapor deposition technique ${ }^{12-14}$. While, examples based on solution processed bulk heterojunction solar cells using metallophthalocyanine complexes are scarce and the corresponding power conversion efficiencies are still low compared with that of polymer solar cells. In the past, phthalocyanines have been repeatedly tested as photosensitizers for dye-sensitized solar cells $^{15-18}$. However, poor incident photon-to-electric current conversion yields were obtained. This may be due to the poor solubility of the macrocycle in organic solvent, a strong tendency to aggregation on the film surface, lack of directionality in the excited state and easy electron recombination between injected electron in $\mathrm{TiO}_{2}$ conduction band and oxidized dye. For this reason, one of the important aims of research on the chemistry of phthalocyanines is to enhance their solubility in common organic solvents. Also, the presence of suitable substituent is known to offer a useful way of regulating the wavelength of the $\mathrm{Q}$ band ${ }^{19-21}$.

A series of low band-gap donor- $\pi$-acceptor conjugatesfunctionalized zinc phthalocyanine: 2-(N,N-bisacetic acid amino)-9,16,23-(N,N-bisethylamino)zinc phthalocyanine (SPC), 2-(N,N-bisacetic acid amino)-9,16,23-(N,N-bispropylamino)zinc phthalocyanine (TPC), 2-(N,N-bisacetic acid amino)-9,16,23-(N,N-bisbutylamino)zinc phthalocyanine (FPC) were designed and synthesized and their photovoltaic properties were studied (Scheme-I). The central zinc phthalocyanine has high extinction coefficiency at around $700 \mathrm{~nm}$, corresponding to the photo flux of solar spectrum, as well as excellent hole-transport ability. The substituents of N,Nbisethylamino, N,N- bispropylamino and N,N-bisbutylamino enhance the solubility of phthalocyanine in common organic solvents, reduce the aggregation. The presence of carboxylic 


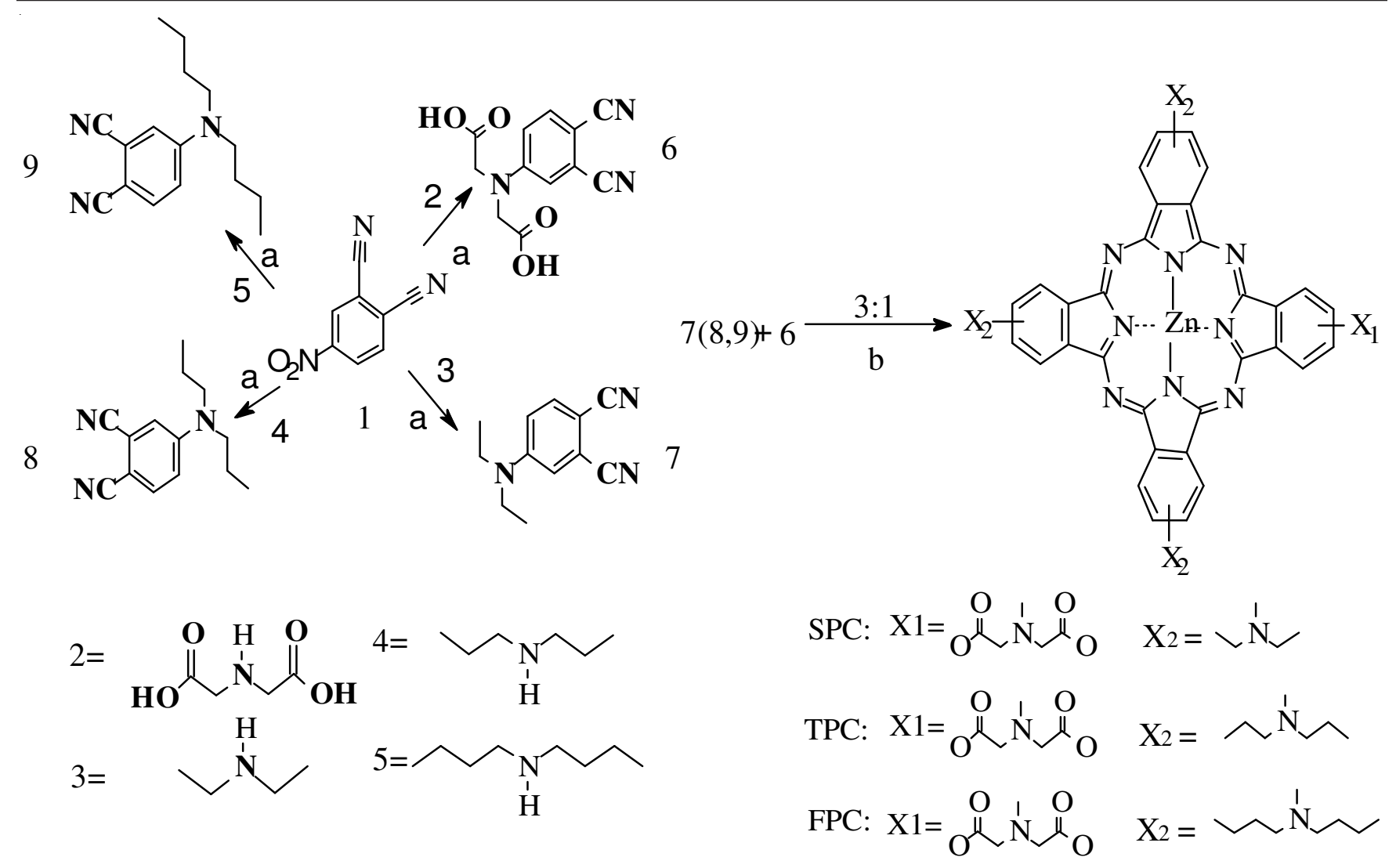

Scheme-I: (a) $\mathrm{K}_{2} \mathrm{CO}_{3}$, DMF and (b) DBU, 1-pentanol, $\mathrm{Zn}\left(\mathrm{CH}_{3} \mathrm{COO}\right)_{2}$

acid act as electron acceptors for the study of photo induced electron transfer processes as well as grafting onto nanocrystalline $\mathrm{TiO}_{2}$. The effects of the substituent are discussed. The solution electrochemistry of the complexes is also investigated.

\section{EXPERIMENTAL}

4-Nitro-phthalonitrile, iminodiacetic acid, N,N-diethylamine, N,N-dipropylamine, N,N-dibutylamine, 1,8-diazabicyclo[5.4.0]-undec-7-ene (DBU), 1-pentanol, anhydrous $\mathrm{K}_{2} \mathrm{CO}_{3}$, DMF, were purchased commercially. DMF was dried and distilled by accustomed methods before use. All other solvents and chemicals used in this work were analytical grade and used without further purification. Column chromatography was performed on silica gel (80-100 mesh).

Synthesis of 4-(N,N-bisacetic acid amino)phthalonitrile (1): 4-Nitro-phthalonitrile $(0.866 \mathrm{~g}, 5 \mathrm{mmol})$ and iminodiacetic acid $(0.666 \mathrm{~g}, 5 \mathrm{mmol})$ were added successively with stirring to dry DMF $(10 \mathrm{ml})$. After dissolution, anhydrous $\mathrm{K}_{2} \mathrm{CO}_{3}(1 \mathrm{~g}$, $7 \mathrm{mmol}$ ) was added and the reaction mixture was stirred at $60{ }^{\circ} \mathrm{C}$. Further $\mathrm{K}_{2} \mathrm{CO}_{3}(0.5 \mathrm{~g}, 3.5 \mathrm{mmol})$ was added portionwise after $2 \mathrm{~h}$. Stirring vigorously for $48 \mathrm{~h}$ under nitrogen. Then the reaction mass was poured into $150 \mathrm{~mL}$ of cold water and stirred for $15 \mathrm{~min}$. The precipitate was filtered, washed several times with cold water until the filtrate became neutral and crystallized from EtOH-water to give the product as a dark yellow, crystalline powder. Yield: $0.78 \mathrm{~g}, 60.2 \%$, m.p. 140-142 ${ }^{\circ} \mathrm{C}$. IR (KBr, $\left.v_{\max }, \mathrm{cm}^{-1}\right): 3423(-\mathrm{O}-\mathrm{H}), 3107$ (H-Ar), $2241(-\mathrm{C}=\mathrm{N}), 1535$ (Ar C=C), 1354 (Ar-O-Ar), $1298(\mathrm{C}-\mathrm{N})$. ${ }^{1} \mathrm{H}$ NMR (DMSO- $d_{6}$ ) $\delta$, ppm: 7.19-8.35 (m, 3H, Ar-H), 2.53 (s, 4H, - $\mathrm{CH}_{2-}$ ). Anal. calcd. for $\mathrm{C}_{12} \mathrm{H}_{9} \mathrm{~N}_{3} \mathrm{O}_{4}(259.22 \mathrm{~g} / \mathrm{mol})$ : $\mathrm{C}$, 55.60; H, 3.50; N, 16.21; O, 24.69 Found: C, 55.21; H, 3.92; N, 16.27 .

Synthesis of 4-(N,N-bisethylamino)phthalonitrile (2): A similar synthetic and purification procedure as for $\mathbf{1}$ was followed for 2 using N,N-diethylamine instead of iminodiacetic acid and keeping reaction temperature at $60^{\circ} \mathrm{C}$. Then the brown solid 2 was obtained. Yield: 1.43 g, $71.8 \%$, m.p. $136-139^{\circ} \mathrm{C}$. IR $\left(\mathrm{KBr}, v_{\max }, \mathrm{cm}^{-1}\right): 3107(\mathrm{H}-\mathrm{Ar}), 2241(-\mathrm{C}=\mathrm{N}), 1537(\mathrm{Ar}$ $\mathrm{C}=\mathrm{C}), 1354$ (Ar-O-Ar) , $1298(\mathrm{C}-\mathrm{N}) .{ }^{1} \mathrm{H}$ NMR (DMSO- $\left.d_{6}\right) \delta$, ppm: 8.64-8.96 (m, 3H, Ar-H), 2.53 (q, 4H, - $\mathrm{CH}_{2}$ ), 2.94 (t, $\left.6 \mathrm{H},-\mathrm{CH}_{3}\right)$. Anal. Calc. for $\mathrm{C}_{12} \mathrm{H}_{13} \mathrm{~N}_{3}(199.26 \mathrm{~g} / \mathrm{mol})$ : C, 72.34; H, 6.58; N, 21.09; Found: C, 72.57; H, 6.42; N, 21.18.

Synthesis of 4-(N,N-bispropylamino)phthalonitrile (3): A similar synthetic and purification procedure as for $\mathbf{1}$ was followed for $\mathbf{3}$ using N,N-dipropylamine instead of iminodiacetic acid and keeping reaction temperature at $60{ }^{\circ} \mathrm{C}$. Then the brown solid 3 was obtained. Yield: $1.52 \mathrm{~g}, 66.9 \%$, m.p. 147-149 ${ }^{\circ} \mathrm{C}$. IR $\left(\mathrm{KBr}, v_{\max }, \mathrm{cm}^{-1}\right): 3088(\mathrm{H}-\mathrm{Ar}), 2240(-\mathrm{C}=\mathrm{N})$, 1533 (Ar C=C), 1356 (Ar-O-Ar) , 1298 (C-N). ${ }^{1} \mathrm{H}$ NMR (DMSO-d $\left.)_{6}\right) \delta$, ppm: 8.31-8.93 (m, 3H, Ar-H), 2.53 (q, 4H, $\left.-\mathrm{CH}_{2-}\right), 2.94\left(\mathrm{t}, 6 \mathrm{H},-\mathrm{CH}_{3}\right), 2.76\left(\mathrm{~m}, 4 \mathrm{H},-\mathrm{CH}_{2-}\right)$. Anal. calcd. for $\mathrm{C}_{14} \mathrm{H}_{17} \mathrm{~N}_{3}(227.31 \mathrm{~g} / \mathrm{mol})$ : C, 73.98; H, 7.54; N, 18.49; Found: C, 73.62; H, 7.38; N, 18.13.

Synthesis of 4-(N,N-bisbutylamino)phthalonitrile (4): A similar synthetic and purification procedure as for $\mathbf{1}$ was followed for 4 using N,N-dibutylamine instead of iminodiacetic acid and keeping reaction temperature at $60{ }^{\circ} \mathrm{C}$. Then the brown solid 4 was obtained. Yield: 1.93g, 75.6\%, m.p. 130-133 ${ }^{\circ} \mathrm{C}$. IR $\left(\mathrm{KBr}, \mathrm{v}_{\max }, \mathrm{cm}^{-1}\right): 3085(\mathrm{H}-\mathrm{Ar}), 2240(-\mathrm{C}=\mathrm{N})$, 
1533 (Ar C=C), 1354 (Ar-O-Ar), $1298(\mathrm{C}-\mathrm{N}) .{ }^{1} \mathrm{H}$ NMR (DMSO- $d_{6}$ ) $\delta$, ppm: 8.25-8.87 (m, 3H, Ar-H), 2.53 (q, 4H, $\left.-\mathrm{CH}_{2-}\right), 2.94\left(\mathrm{t}, 6 \mathrm{H},-\mathrm{CH}_{3}\right), 2.76\left(\mathrm{~m}, 4 \mathrm{H},-\mathrm{CH}_{2}-\right), 2.54(\mathrm{~m}, 4 \mathrm{H}$, $\left.-\mathrm{CH}_{2}-\right)$. Anal. Calcd. for $\mathrm{C}_{16} \mathrm{H}_{21} \mathrm{~N}_{3}(255.36 \mathrm{~g} / \mathrm{mol})$ : C, 75.26; H, 8.29; N, 16.46; Found: C, 75.02; H, 8.47; N, 16.19.

2-(N,N-bisacetic acid amino)-9,16,23-(N,N-bisethylamino)zinc phthalocyanine (SPC): 4-(N,N-bisacetic acid amino)phthalonitrile $(0.13 \mathrm{~g}, 0.5 \mathrm{mmol}), 4-(\mathrm{N}, \mathrm{N}-$ bisethylamino)phthalonitrile $(0.3 \mathrm{~g}, 1.5 \mathrm{mmol}), \mathrm{Zn}\left(\mathrm{CH}_{3} \mathrm{COO}\right)_{2}(0.11$, $0.5 \mathrm{mmol}$ ) and a catalytic amount of DBU in dry 1-pentanol $(10 \mathrm{~mL})$ was heated at $160{ }^{\circ} \mathrm{C}$ with stirring under nitrogen for $24 \mathrm{~h}$. After cooling to room temperature, the reaction mixture was precipitated by adding methanol. The product was separated by filtration as a green solid which was washed several times with methanol and ethanol to remove any unreacted precursor and then dried in vacuo. The solid material was subjected to silica gel column chromatography and eluted with DMF: $\mathrm{CHCl}_{3}: \mathrm{CH}_{3} \mathrm{OH}=2: 8: 2(\mathrm{v} / \mathrm{v})$ and bluish color band was collected. The solvent was removed under reduced pressure to get the desired product. Yield: $0.25 \mathrm{~g}, 54.2 \%$, m.p. $>200{ }^{\circ} \mathrm{C}$. IR $\left(\mathrm{KBr}, \mathrm{v}_{\max }, \mathrm{cm}^{-1}\right): 3431(-\mathrm{O}-\mathrm{H}), 2922,2853,1720$ $(-\mathrm{C}=\mathrm{O}), 1618,1400,1650,1458(\mathrm{C}=\mathrm{C}), 1298(\mathrm{C}-\mathrm{N}), 1340$, 1122,727 . UV-Vis, in DMF ( $\left.\lambda_{\max }, \log \varepsilon\right) 686$ (4.37), 646 (4.05). ${ }^{1} \mathrm{H}$ NMR (DMSO- $d_{6}$ ) $\delta$, ppm: 7.15-8.13 (m, 12H, Ar-H), 4.34 (s, 4H, $-\mathrm{CH}_{2}$ ), $2.31-2.85\left(\mathrm{~m}, 30 \mathrm{H},-\mathrm{CH}_{2} \mathrm{CH}_{3}\right)$. Anal. calcd. for $\mathrm{C}_{48} \mathrm{H}_{48} \mathrm{~N}_{12} \mathrm{O}_{4} \mathrm{Zn}(922.37 \mathrm{~g} / \mathrm{mol}): \mathrm{C}, 62.51 ; \mathrm{H}, 5.25 ; \mathrm{N}, 18.22$; O, 6.94; Zn, 7.09 Found: C, 62.76; H, 5.37; N, 18.14 .

2-(N,N-bisacetic acid amino)-9,16,23-(N,N-bispropylamino)zinc phthalocyanine (TPC): A similar synthetic and purification procedure as for SPC was followed for TPC using 4-(N,N-bispropylamino)phthalonitrile instead of 4-(N,N-bisethylamino)phthalonitrile acid and keeping reaction temperature at $160{ }^{\circ} \mathrm{C}$. Then the desired product was obtained. Yield: $0.23 \mathrm{~g}, 45.7 \%$, m.p. $>200^{\circ} \mathrm{C}$. IR $\left(\mathrm{KBr}, v_{\max }, \mathrm{cm}^{-1}\right): 3400(-\mathrm{O}-$ H), 2930, 2856, 1717 (-C=O), 1616, 1398, 1647, 1440 (C=C), $1200(\mathrm{C}-\mathrm{N}), 1344,1080,721 . \mathrm{UV}$-vis, in DMF $\left(\lambda_{\max }, \log \varepsilon\right)$ 690 (4.52), 649 (4.16). ${ }^{1} \mathrm{H}$ NMR (DMSO- $\left.d_{6}\right) \delta$, ppm: 7.157.93 (m, 12H, Ar-H), 4.33 (s, 4H, - $\left.\mathrm{CH}_{2-}\right), 2.11-2.89$ (m, 42H, $-\mathrm{CH}_{2} \mathrm{CH}_{3}$ ). Anal. calcd. for $\mathrm{C}_{54} \mathrm{H}_{60} \mathrm{~N}_{12} \mathrm{O}_{4} \mathrm{Zn}(1006.53 \mathrm{~g} / \mathrm{mol})$ : C, 64.44; H, 6.01; N, 16.70; O, 6.36; Zn, 6.50 Found: C, 64.23; $\mathrm{H}, 6.28 ; \mathrm{N}, 16.87$.

2-(N,N-bisacetic acid amino)-9,16,23-(N,N-bisbutylamino) zinc phthalocyanine (FPC): A similar synthetic and purification procedure as for SPC was followed for FPC using 4-(N,N-bisbutylamino)phthalonitrile instead of 4-(N,Nbisethylamino)phthalonitrile acid and keeping reaction temperature at $160{ }^{\circ} \mathrm{C}$. Then the desired product was obtained. Yield: $0.24 \mathrm{~g}, 44.0 \%$, m.p. $>200{ }^{\circ} \mathrm{C}$. IR $\left(\mathrm{KBr}, v_{\max }, \mathrm{cm}^{-1}\right)$ : 3393 (-O-H), 2928, 2858, 1720 (-C=O), 1616, 1398, 1649, $1398(\mathrm{C}=\mathrm{C}), 1248(\mathrm{C}-\mathrm{N}), 1340,1094,723$. UV-vis, in DMF $\left(\lambda_{\max }, \log \varepsilon\right) 687$ (4.41), 648 (4.28). ${ }^{1} \mathrm{H}$ NMR (DMSO- $\left.d_{6}\right) \delta$, ppm: 7.25-7.86 (m, 12H, Ar-H), 4.27 (s, 4H, - $\left.\mathrm{CH}_{2-}\right), 2.24-$ $2.81\left(\mathrm{~m}, 54 \mathrm{H},-\mathrm{CH}_{2} \mathrm{CH}_{3}\right)$. Anal. Calcd. for $\mathrm{C}_{60} \mathrm{H}_{72} \mathrm{~N}_{12} \mathrm{O}_{4} \mathrm{Zn}$ (1090.69 g/mol): C, 66.07; H, 6.65; N, 15.41; O, 5.87; Zn, 5.99 Found: C, 66.25; H, 6.35; N, 15.53 .

The UV-visible spectra were recorded with a Techcomp 2300 spectrophotometer. The Fourier transform IR (FTIR) spectra of all the samples were measured using a Shimadzu 4800S spectrophotometer. ${ }^{1} \mathrm{H}$ NMR spectra were obtained at
$400 \mathrm{MHz}$ using a Varian Inova $400 \mathrm{MHz}$ NMR system. The chemical shifts are relative to tetramethylsilane (TMS). Elemental analyses were performed on a Flash EA1112 Elemental Analyzer.

Cyclic and differential pulse voltammetry measurements were performed on an electrochemical workstation (CHI LK2005A, Tianjin Lanlike Chemistry Electronic High-tech Co., Ltd., P.R. China). Cyclic voltammetry experiments were performed on $1 \times 10^{-4} \mathrm{~mol} / \mathrm{L}$ phthalocyanine dye solution in $\mathrm{DMF}$ at scan rate $100 \mathrm{mV} / \mathrm{s}$ using tetrabutylammonium perchlorate $(0.1 \mathrm{~mol} / \mathrm{L})$ as supporting electrolyte. A platinum wire was used as working electrode, the other platinum as the counter film electrode, the calomel (SCE) as the reference.

Photoelectrode preparation: $\mathrm{TiO}_{2}$ photoelectrode (area: $0.74 \mathrm{~cm}^{2}$ ) was prepared by a similar method reported in the literature ${ }^{22-24} \cdot \mathrm{TiO}_{2}$ anatase nanoparticles of $19 \mathrm{~nm}$ were procured from Solaronix. Nanocrystalline $\mathrm{TiO}_{2}$ films of $6 \mu \mathrm{m}$ were deposited onto transparent conducting glass (the glass had been coated with a fluorine-doped stannic oxide layer (FTO); sheet resistance $8-10 \Omega$ /square) by screen-printing technique. Nanocrystalline $\mathrm{TiO}_{2}$ films were heated to $450{ }^{\circ} \mathrm{C}$ in an oxygen atmosphere and calcinated for $45 \mathrm{~min}$. The dye was dissolved in organic solvents at a concentration of $0.5 \times$ $10^{-4} \mathrm{M}$. The $\mathrm{TiO}_{2}$ films were soaked in the dye solution and then kept at room temperature for $16 \mathrm{~h}$ so that the dye was adsorbed onto $\mathrm{TiO}_{2}$ films. The photoelectrode was dipped into the dye solution while it was still hot, its temperature was $80^{\circ} \mathrm{C}$. After completion of the dye adsorption, the photoelectrode was withdrawn from the solution and washed thoroughly with either THF or ethanol to remove non-adsorbed dye under a stream of dry air or argon. A sandwich cell was prepared using the dye-sensitized electrode and platinum coated conducting glass electrode as the counter electrode. The latter was prepared by chemical deposition of plantinum from $0.05 \mathrm{M}$ hexachloroplatinic acid. The two electrodes were placed on top of each other using a thin polyethylene film $(50 \mu \mathrm{m}$ thick $)$ as a spacer to form the electrolyte space. The empty cell was tightly held and edges were heated to $130{ }^{\circ} \mathrm{C}$ to seal the two electrodes together. The active surface area of the $\mathrm{TiO}_{2}$ film electrode was $0.74 \mathrm{~cm}^{2}$. The redox electrolyte was introduced into the cell through a predrilled hole of the counter electrode, which was later closed by a cover glass to avoid the leakage of the electrolyte solution. The composition of redox electrolyte is $0.05 \mathrm{~mol} / \mathrm{L}$ iodine, $0.5 \mathrm{~mol} / \mathrm{L}$ lithium iodide in acetonitrile.

\section{RESULTS AND DISCUSSION}

The synthesis of SPC, TPC and FPC were illustrated in Scheme-I. The phthalonitrile derivatives (6-9) were obtained through displacement reaction of 4-nitrophthalonitrile with iminodiacetic acid, N,N-diethylamine, N,N-dipropylamine, N,N-dibutylamine, respectively. SPC, TPC and FPC were prepared through 4-(N,N-bisethylamino)phthalonitrile (7), 4(N,N-bispropylamino)phthalonitrile $(8)$ and 4- $(\mathrm{N}, \mathrm{N}-$ bisbutylamino)phthalonitrile (9) with 4-(N,N-bisaceticacidamino)phthalonitrile (6), (molar ratio of 3:1), respectively, in 1-pentanol solution in the presence of DBU and metal salts.

Compounds SPC, TPC and FPC were characterized by ${ }^{1} \mathrm{H}$ NMR, UV-visible, IR and elemental analysis. For the IR spectra of SPC, TPC and FPC, it is clear that the strong imido- 
groups vibration was appeared at about $1700 \mathrm{~cm}^{-1}$. Further, the following UV-visible spectra reveal some special properties of SPC, TPC and FPC in terms of the impact of substituent. These characteristic results were consistent with the proposed structures (Scheme-I).

UV-visible and electrochemical measurements: Figs. 1-3 show absorption spectrum of SPC, TPC and FPC in DMF solution and compared to that of the phthalocyanines adsorbed onto $6 \mu \mathrm{m}$ thick nanocrystalline $\mathrm{TiO}_{2}$ films. The absorption spectrum in solution showed characteristic absorptions between 690 and $646 \mathrm{~nm}$ in the Q band region. The Q band observed was attributed to $\pi-\pi^{*}$ transitions from the highest occupied molecular orbital (HOMO) to the LUMO of the conjugated macrocycle. The other bands (Soret band) in the ultraviolet (UV) region at 343-356 $\mathrm{nm}$ were observed due to the transitions from the deep levels to the LUMO. The absorption spectrum of the phthalocyanines adsorbed onto $6 \mu \mathrm{m}$ thick $\mathrm{TiO}_{2}$ electrode exhibit obvious red shift. The interaction between the carboxylate group and the surface $\mathrm{Ti}^{4+}$ ions may lead to increased delocalization of the $\pi^{*}$ orbital of the conjugated framework. The energy of the $\pi^{*}$ level is decreased by this delocalization, which explains the red shift for the absorption

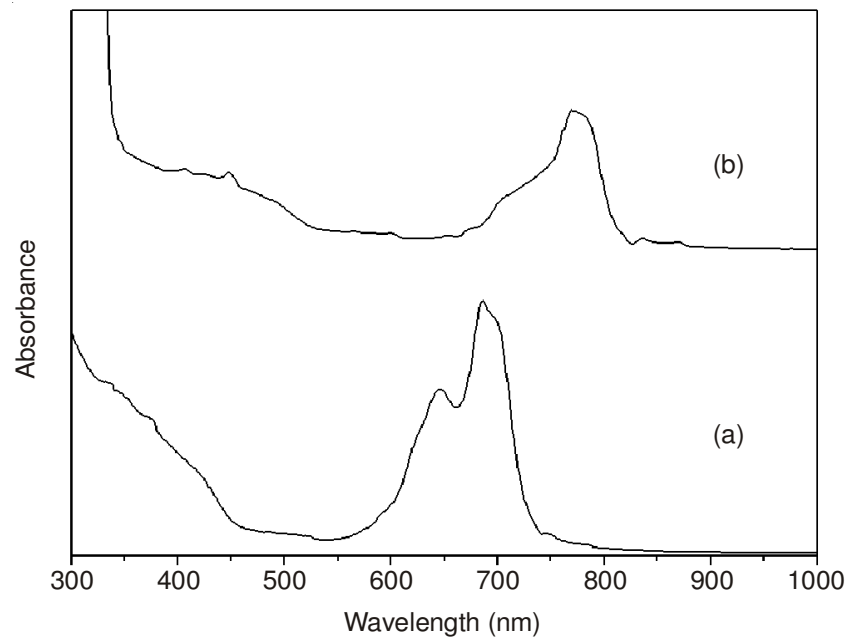

Fig. 1. UV-visible absorption spectra of SPC (a) in DMF and (b) adsorbed onto a $6 \mu \mathrm{m}$ thick $\mathrm{TiO}_{2}$ films

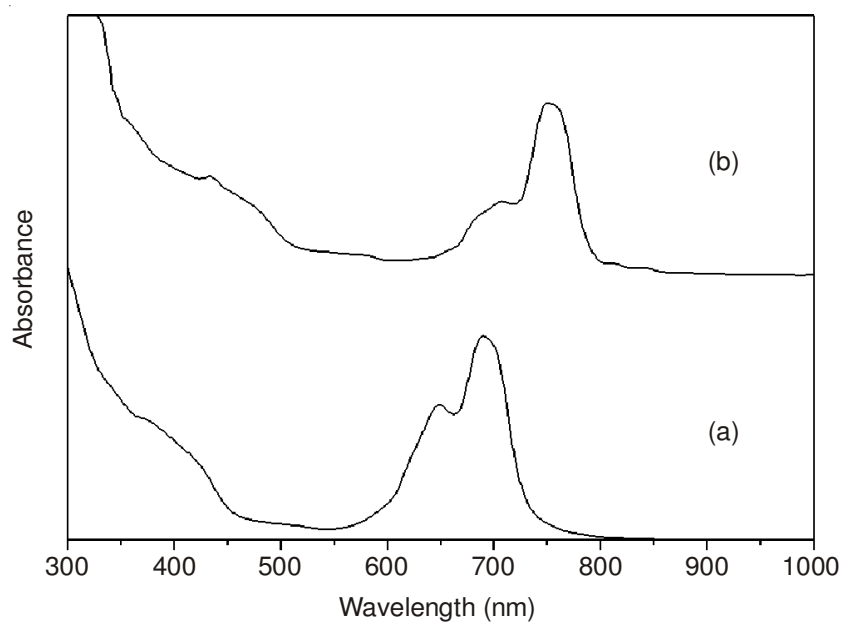

Fig. 2. UV-visible absorption spectra of TPC (a) in DMF and (b) adsorbed onto a $6 \mu \mathrm{m}$ thick $\mathrm{TiO}_{2}$ films

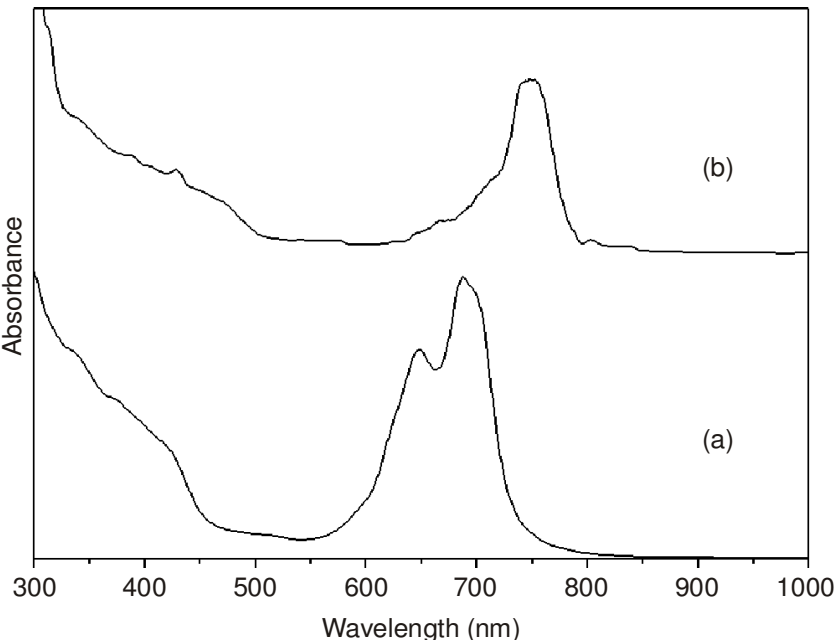

Fig. 3. UV-visible absorption spectra of FPC (a) in DMF and (b) adsorbed onto a $6 \mu \mathrm{m}$ thick $\mathrm{TiO}_{2}$ films.

threshold ${ }^{25,26}$. SPC, TPC and FPC adsorbed onto nanocrystalline $\mathrm{TiO}_{2}$ films not only broaden the range of nanocrystalline $\mathrm{TiO}_{2}$ films spectral response, but also conducive to inject electrons into the conduction band of $\mathrm{TiO}_{2}$. The $\mathrm{E}_{0-0}$ was calculated according to the following equation.

$$
\mathrm{E}_{0-0}=\frac{1240}{\lambda_{\max }}
$$

$\lambda_{\max }$ is the absorption maximum.

UV-visible data for SPC, TPC and FPC in DMF is shown in Table-1. $\mathrm{E}_{0-0}$ energy of SPC, TPC and FPC estimated from absorption maximum is $1.81,1.80,1.80 \mathrm{eV}$, respectively.

\begin{tabular}{|c|c|c|}
\hline \multicolumn{3}{|c|}{$\begin{array}{c}\text { TABLE-1 } \\
\text { UV-Visible DATA FOR SPC, TPC AND FPC IN DMF }\end{array}$} \\
\hline Compound & $\begin{array}{l}\text { Absorption } \lambda_{\max }, \mathrm{nm}(\log \varepsilon \\
\left.\mathrm{mol}^{-1} \mathrm{~cm}^{-1}\right)\end{array}$ & $\mathrm{E}_{0-0}(\mathrm{eV})$ \\
\hline SPC & $646(4.05) \quad 686(4.37)$ & 1.81 \\
\hline $\mathrm{TPC}$ & $649(4.16) \quad 690(4.52)$ & 1.80 \\
\hline FPC & $687(4.41)$ & 1.80 \\
\hline
\end{tabular}

The reduction and oxidation behavior of metallophthalocyanine derivatives is due to the interaction between the phthalocyanine ring and the central metal. First-row transition metal phthalocyanines differ from those of the main-group metal phthalocyanines due to the fact that metal ' $d$ ' orbitals may be positioned between the HOMO and LUMO of the phthalocyanine ligand ${ }^{27,28}$. To get an efficient charge separation, the HOMO and LUMO levels of SPC, TPC and FPC must match with the conduction-band-edge energy level of the $\mathrm{TiO}_{2}$ and the redox potential of electrolyte for efficient electron injection and SPC, TPC and FPC regeneration. The electrochemical behavior of SPC, TPC and FPC were investigated using cyclic and differential pulse voltammetric techniques in DMF solvent. The oxidation potentials were determined from half-wave potentials $\left(E_{1 / 2}\right)\left(E_{o x}-E_{\text {red }}\right) / 2$ by cyclic voltammetry or peak potentials by differential pulse voltammetry. The corresponding cyclic and differential pulse voltammograms were presented in Figs. 4-6. The first oxidation potentials ( $\left.E_{1 / 2(\mathrm{ox})}\right)$ correspond to the HOMO level of phthalocyanines. The SPC, TPC and FPC exhibit quasi-reversible oxidation at 0.85, 0.9, 


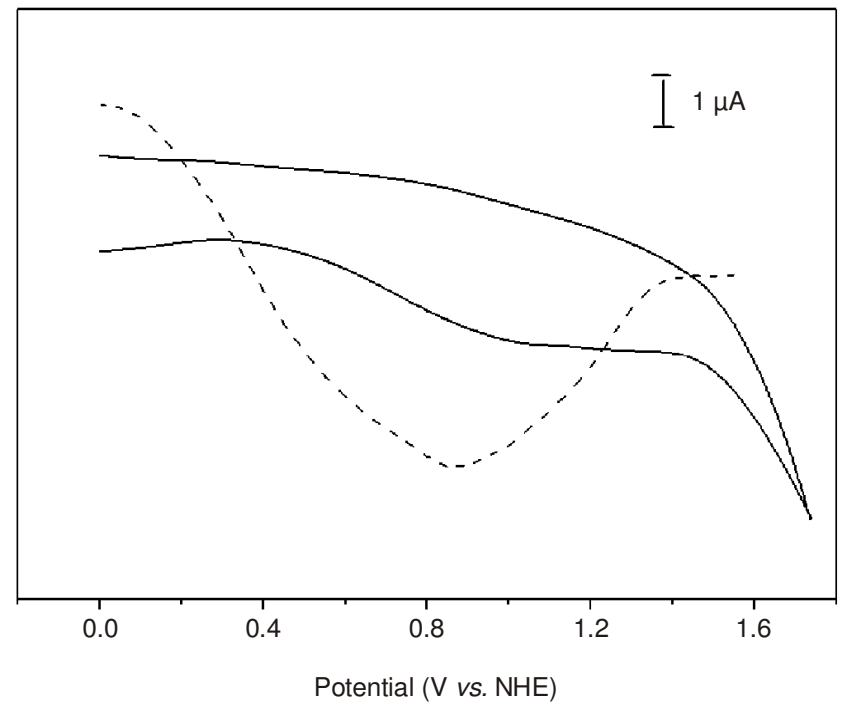

Fig. 4. Cyclic (-) and differential pulse voltammograms (---) of SPC in DMF

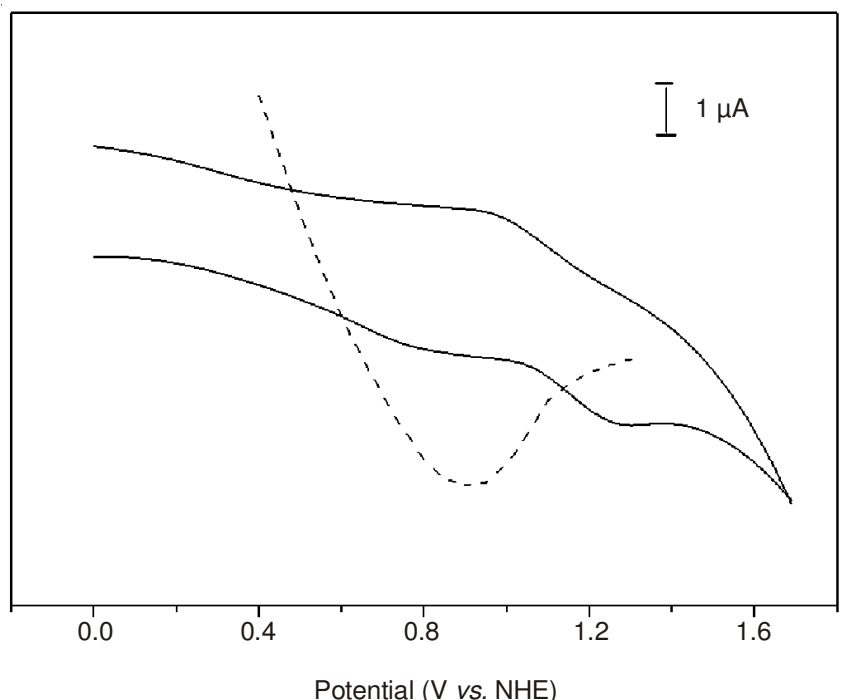

Fig. 5. Cyclic (-) and differential pulse voltammograms (---) of TPC in $\mathrm{DMF}$

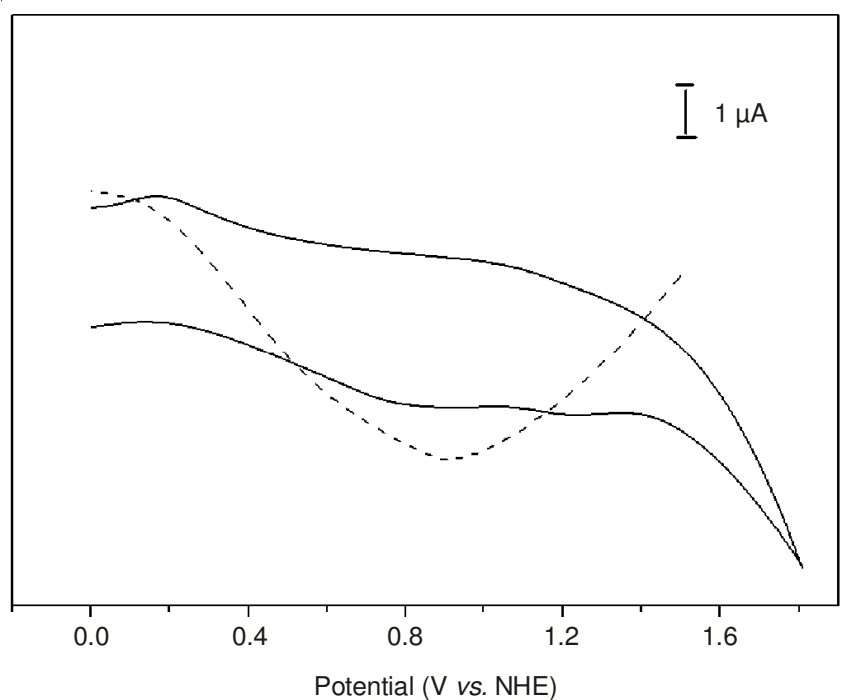

Fig. 6. Cyclic (-) and differential pulse voltammograms (---) of FPC in $\mathrm{DMF}$
$0.9 \mathrm{~V}$ respectively. With respect to dye-sensitization of wideband gap semiconductors, e.g. $\mathrm{TiO}_{2}$, the first oxidation potentials of SPC, TPC and FPC and the $\mathrm{E}_{0-0}$ transition energy, the energy levels of the LUMO were deduced to be $-0.96 \mathrm{~V} v s$. SCE, -0.9 $\mathrm{V} v$ s. SCE and $-0.9 \mathrm{~V} v$ s. SCE, respectively. The LUMO is calculated according to the following equation.

$$
\text { LUMO }=\text { HOME }-\mathrm{E}_{0-0}
$$

The energy level of the conduction band edge of $\mathrm{TiO}_{2}$ is $-0.74 \mathrm{~V}$ vs. $\mathrm{SCE}^{29}$. This makes electron injection from the excited state of SPC, TPC and FPC into the conduction band of $\mathrm{TiO}_{2}$ thermodynamically feasible. The HOMO levels of SPC, TPC and FPC are more positive than the energy level of the redox couple $\mathrm{I}^{-} / \mathrm{I}_{3}(0.2 \mathrm{~V} v s$. SCE $)$ in the electrolyte, indicating more efficient phthalocyanines regeneration by electron transfer from I. Fig. 7 shows the schematic energy diagram of SPC, TPC and FPC dye-sensitized $\mathrm{TiO}_{2}$ electrodes. SPC, TPC and FPC have negative LUMO levels and positive HOMO levels, satisfying the energy gap rule. This means that, the SPC, TPC and FPC can be employed as sensitizers for dyesensitized solar cells applications ${ }^{30}$. SPC has stronger electron injection than TPC and FPC. Data of electrochemistry for SPC, TPC and FPC in DMF are shown in Table-2.

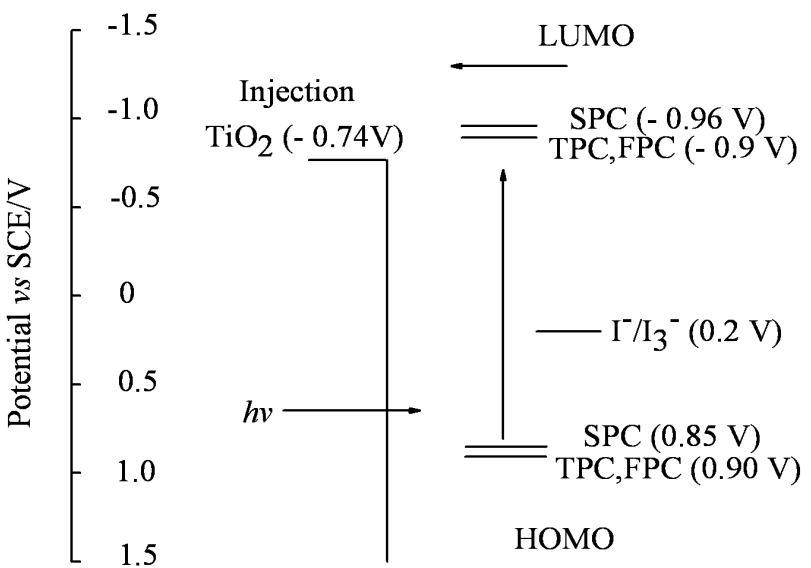

Fig. 7. Energy level diagram for SPC, TPC and FPC

\begin{tabular}{ccc}
\multicolumn{3}{c}{ TABLE-2 } \\
DATA OF ELECTROCHEMISTRY FOR SPC, TPC \\
AND FPC IN DMF
\end{tabular}

Photovoltaic characterization: The solar energy-toelectricity conversion efficiency, $\eta$, under white light irradiation can be obtained from the following equation.

$$
\eta[\%]=\frac{\mathrm{J}_{\mathrm{SC}}\left[\mathrm{mAcm}^{-2}\right] \mathrm{V}_{\mathrm{OC}}[\mathrm{V}] \mathrm{Xff}}{\mathrm{I}_{0}\left[\mathrm{WM}^{-2}\right]} \times 100
$$

where $\mathrm{I}_{0}$ is the photon flux (1000 W m $\mathrm{W}^{-2}$ for 1.0 sun), $\mathrm{J}_{\mathrm{SC}}$ is the short-circuit photocurrent density under irradiation, $\mathrm{V}_{\mathrm{OC}}$ is the open-circuit voltage and $\mathrm{ff}$ represents the fill factor. The fill factor is defined by the following equation.

$$
\mathrm{ff}=\frac{\mathrm{J}_{\mathrm{PH}(\max )} \mathrm{V}_{\mathrm{PH}(\max )}}{\mathrm{J}_{\mathrm{SC}} \mathrm{V}_{\mathrm{OC}}}
$$


where $\mathrm{J}_{\mathrm{PH}(\max )}$ and $\mathrm{V}_{\mathrm{PH}(\max )}$ are the photocurrent and photovoltage for maximum power output and $\mathrm{J}_{\mathrm{SC}}$ and $\mathrm{V}_{\mathrm{OC}}$ are the short-circuit photocurrent density and open-circuit photovoltage. Photovoltaic characterization data for SPC, TPC and FPC grafted onto nanocrystalline $\mathrm{TiO}_{2}$ films is shown in Table- 3 . We have observed an overall efficiency 1.42, 1.67, $1.64 \%$ under 1 sun irradiation.

\begin{tabular}{ccccc}
\multicolumn{6}{c}{ TABLE-3 } \\
\multicolumn{5}{c}{ DATA OF PHOTOVOLTAIC CHARACTERIZATION } \\
FOR SPC, TPC AND FPC \\
\hline DSSC & $\mathrm{J}_{\mathrm{SC}}\left(\mathrm{mA} \mathrm{cm}^{-2}\right)$ & $\mathrm{V}_{\mathrm{OC}}(\mathrm{V})$ & $\mathrm{ff}$ & $\eta(\%)$ \\
\hline $\mathrm{SPC}$ & 1.53 & 0.48 & 0.57 & 1.42 \\
$\mathrm{TPC}$ & 2.07 & 0.55 & 0.59 & 1.67 \\
$\mathrm{FPC}$ & 1.89 & 0.56 & 0.60 & 1.64 \\
\hline
\end{tabular}

The low overall conversion efficiency of SPC, TPC and FPC adsorbed onto $\mathrm{TiO}_{2}$ was due to the solubility, aggregation and poor electron injection from excited state of phthalocyanine into the conduction band of $\mathrm{TiO}_{2}{ }^{31-33}$.

\section{Conclusion}

The new unsymmetrical zinc phthalocyanines, SPC, TPC and FPC based on 'push-pull' or donor- $\pi$-acceptor conjugates concept, were successfully prepared and characterized. The presence of carboxylic acid acted as electron acceptors ('pull') and server to graft onto nanocrystalline $\mathrm{TiO}_{2}$. The surface aggregation of SPC, TPC and FPC adsorbed onto $\mathrm{TiO}_{2}$ was not significantly avoided. The new photosensitizes were tested in dye-sensitized solar cells by using $\mathrm{I}^{-} / \mathrm{I}_{3}{ }^{-}$redox electrolyte, the dye-sensitized solar cells had been fabricated.

\section{ACKNOWLEDGEMENTS}

The authors acknowledged the financial support from the National Nature Science Foundation of China (Grant No.: 20871108) and the Natural Science Foundation of Shanxi Province, China (Grant Number: 2011011022-4).

\section{REFERENCES}

1. H.Y. Chen, J. Hou, S. Zhang, Y. Liang, G. Yang, Y. Yang, L. Yu, Y. Wu and G. Li, Nat. Photonics, 3, 649 (2009).

2. K. Schulze, C. Uhrich, R. Schüppel, K. Leo, M. Pfeiffer, E. Brier, E. Reinold and P. Bäuerle, Adv. Mater., 18, 2872 (2006).

3. T.M. Pappenfus, M.W. Burand, D.E. Janzen and K.R. Mann, Org. Lett., 5, 1535 (2003).

4. P. Suresh, P. Balraju, G.D. Sharma, J.A. Mikroyannidis and M.M. Stylianakis, ACS Appl. Mater., 1, 1370 (2009).
5. M.-S. An, S.-W. Kim and J.-D. Hong, Bull. Korean Chem. Soc., 31, 3272 (2010).

6. X. Li, A. Liu, S. Xun, W. Qiao, X. Wan and Z.Y. Wang, Org. Lett., 10, 3785 (2008)

7. G. Qian, Z. Zhong, M. Luo, D. Yu, Z. Zhang, Z.Y. Wang and D. Ma, Adv. Mater., 21, 111 (2009).

8. F. Zhang, W. Mammo, L.M. Andersson, S. Admassie, M.R. Andersson and O. Inganäs, Adv. Mater., 18, 2169 (2006).

9. S.-G. Yim and T.S. Jones, Bull. Korean Chem. Soc., 31, 2247 (2010).

10. N. Blouin, A. Michaud and M. Leclerc, Adv. Mater., 19, 2295 (2007).

11. 11. G.-S. Park, I.-S. Heo, I.-H. Ryu and S.-G. Yim, Bull. Korean Chem. Soc., 32, 943 (2011).

12. I. Kim, H.M. Haverinen, Z. Wang, S. Madakuni, Y. Kim, J. Li and G.E. Jabbour, Chem. Mater., 21, 4256 (2009).

13. C. Yoon, J.-H. Choi and J.-P. Kim, Bull. Korean Chem. Soc., 32, 1033 (2011).

14. J. Xue, B.P. Rand, S. Uchida and S.R. Forrest, Adv. Mater., 17, 66 (2005).

15. D. Wohrle and D. Meissner, Adv. Mater., 3, 129 (1991).

16. K.J. Hwang, S.J. Yoo, S.H. Jung, D.W. Park, S.I. Kim and J.W. Lee, Bull. Korean Chem. Soc., 30, 172 (2009).

17. M.K. Nazeeruddin, R. Humphry-Baker, M. Grätzel and B.A. Murrer, Chem. Commun., 719 (1998).

18. M.S An, S.J. Kim and D. Hong, Bull. Korean Chem. Soc., 31, 3272 (2010).

19. M.J. Cook, J. Mater. Chem., 6, 677 (1996).

20. S. Vagin and M. Hanack, Eur. J. Org. Chem., 14, 2661 (2003).

21. Y.S. Ko, M.H. Kim and Y.U. Kwon, Bull. Korean Chem. Soc., 29, 463 (2008).

22. C.J. Barbe, F. Arendse, P. Comte, M. Jirousek, F. Lenzmann, V. Shklover and M. Grätzel, J. Am. Chem. Soc., 80, 3157 (1997).

23. P. Wang, S.M. Zakeeruddin, P. Comte, R. Charvet, R. Humphry-Baker and M. Grätzel, J. Phys. Chem. B, 107, 14336 (2003).

24. M.K. Nazeeruddin, F. De Angelis, S. Fantacci, A. Selloni, G. Viscardi, P. Liska, S. Ito, T. Bessho and M. Grätzel, J. Am. Chem. Soc., 127, 16835 (2005).

25. Z.S. Wang, K. Hara, Y. Dan-oh, C. Kasada, A. Shinpo, S. Suga, H. Arakawa and H. Sugihara, J. Phys. Chem. B, 109, 3907 (2005).

26. D. Zhang, X.J. Zhang, L. Zhang and L.J. Mao, Bull. Korean Chem. Soc., 33, 1225 (2012).

27. M. Özçesmeci, I. Özçesmeci and E. Hamuryudan, Polyhedron, 29, 2710 (2010).

28. M. Kandaz, N.U. Yarassir Meryem, A. Koca and O. Bekaroglu, Polyhedron, 21, 255 (2002).

29. A. Hagfeldt and M. Grätzel, Chem. Rev., 95, 49 (1995).

30. C.Y. Li, X.C. Yang, R.K. Chen, J.X. Pan, H.N. Tian, H.J. Zhu, X.N. Wang, A. Hagfeldt and L.C. Sun, Solar Energy Mater. Sollar Cells, 91, 1863 (2007).

31. M.K. Nazeeruddin, R. Humphry-Baker, M. Grätzel, D. Wohrle, G. Schnurpfeil, G. Schneider, A. Hirth and N.J. Trombach, Porphyrins Phthalocyan., 3, 230 (1999).

32. H.H. Deng, H.F. Mao, H. Zhang, Z.H. Lu and H.J.J. Xu, Porphyrins Phthalocyan., 2, 171 (1998).

33. X.J. Zhang, L.J. Mao, D. Zhang and L.J. Zhang, J. Mol. Struct., 1022, 153 (2012). 